\title{
Joseph B. Reade (1801-1870) and the earliest studies of fossil dinoflagellate cysts in England
}

\author{
WILLIAM A.S. SARJEANT \\ Department of Geological Sciences, University of Saskatchewan, Saskatoon, Saskatchewan, Canada
}

\begin{abstract}
The earliest British record of fossil dinoflagellate cysts is shown to have been published in 1838, in an appendix to Mantell's The Wonders of Geology. A biography of its author, the Reverend Joseph Bancroft Reade (1801-1870), is presented; it is shown that his discoveries resulted from an awareness of earlier work in Germany and France. Reade is shown, not only to have stimulated Mantell's interest in these microfossils, but also to have perceived their potential value as biostratigraphical indices. The present taxonomic placement of the forms illustrated by Reade in the 1838 note, and in his better-known paper published later in the same year, is summarized.
\end{abstract}

\section{INTRODUCTION}

In November 1838, a paper was published in the Annals of Natural History which featured illustrations of what were then termed "fossil Xanthidia". Its firstpage title is "On some new Organic Remains in the Flint of Chalk". This is almost certainly a misprint, for the running head on subsequent pages "Rev. J.B. Reade on Organic Remains in Flints of the Chalk", makes better sense; nevertheless, the faulty title is correctly used in all subsequent citations. It has long been considered (by the present writer and others) that this paper constituted the first report of these microfossils from Great Britain and indeed, from anywhere outside Germany and France. That there was a yet earlier publication on these microfossils by Reade has hitherto gone unrealized. In view of the present importance of dinoflagellate cysts in geology, especially as stratigraphical indices in the search for petroleum, the historical record needs to be set straight and the importance of Reade's work to be assessed.

\section{HISTORICAL SETTING}

A towering figure in microscopy during the mid19th century was the German naturalist Christian Gottfried Ehrenberg (1795-1876). His classification of the "infusoria" (microscopic animals and plants), published in 1830 , had been described by the great French zoologist Cuvier as "one of those works which define epochs in science" and had come to be universally employed. However, to the geological world, more memorable was the paper delivered by Ehrenberg in July 1836 to the Berlin Academy of Sciences; for, in that paper, he astonished his scientific audience by demonstrating that whole sedimentary strata could be made up almost entirely of the remains of microscopic organisms.

Quite incidentally in this latter paper, two groups of microfossils were described for the first time. One group possessed tests divided into plates and grooved to accommodate two flagella. From his observations of modern plankton, Ehrenberg immediately recognized these as dinoflagellates. The second comprised forms of comparable size (i.e. around 60 to $100 \mu \mathrm{m}$ in diameter) but bristling with processes, in the form of spines or tubes. Supcrficially at least, these resembled closely the zygospores of certain freshwater Desmids discovered earlier by Ehrenberg and placed by him into his new genus Xanthidium. The microfossils of both types were found enclosed in thin, translucent flakes of Mesozoic chalk and flints; they were preserved as three-dimensional objects and very often were in excellent condition, showing no signs, at least under microscopes of the power and quality available to Ehrenberg, of damage. It is scarcely surprising, therefore, that Ehrenberg should have assumed his "fossil xanthidia" to be siliceous and the dinoflagellates to be secondarily silicified.

His systematic attribution of the spiny microfossils was, however, swiftly challenged. Ehrenberg's even more famous compatriot and friend, the scientific polymath Alexander von Humboldt, was deeply interested in his work and sent some of his slides to be displayed in Paris, at a meeting of the French Academy of Sciences. A member of the Academy, C.R. Turpin, examined the slides in January 1837 and soon presented to his colleagues of the Academy an alternative hypothesis, that these were reproductive bodies, not of Desmids, but of a freshwater bryozoan (Cristatella). Turpin's paper was published very early in 1837 and, later in the same year, Ehrenberg responded with a short paper criticising and rejecting Turpin's hypothesis. Unfortunately, Ehrenberg's original paper had been delayed in press and seems not to have been published 
until 1838 (see discussion in Sarjeant, 1970, p. 226); though summaries of it had appeared earlier in various scientific journals, none of them contained any reference to the "xanthidia". Thus, quite inadvertently, Turpin's work on these microfossils gained priority of publication and Ehrenberg's reply $(1837 \mathrm{c})$ seems also to have preceded in publication his original paper!

Ehrenberg's work excited great interest among the numerous British naturalists of his time, to whom microscopy was a fascinating hobby. Among these were a London cleric, the Reverend J.B. Reade, and the great palaeontologist Gideon Algernon Mantell (1790-1852). Between them, these two were to publish some of the earliest, and some of the most significant, observations on these microfossils to be made during the nineteenth century.

\section{READE'S LIFE AND \\ SCIENTIFIC ACHIEVEMENTS}

Of the two principal protagonists in this story, one is well known to geologists through his major contributions to stratigraphy and palaeontology, the other remembered only for the controversy surrounding his part in the discovery of photographic processes. Gideon Algernon Mantell has been the subject of a full biography (Spokes, 1927) and several shorter accounts (notably Spalding, 1966; Morris, 1972; Swinton, 1975). His scientific journal has been published (Curwen, 1940) and, through his discovery of Iguanodon, his name figures prominently in most histories of vertebrate palaeontology.

In contrast, so little has been written on Reade's life and scientific career that a brief account seems appropriate here. The two sources used are the entry in the Dictionary of National Biography (G.S.B., 1917) and a family history printed privately in an edition of only 350 copies (A.L. Reade, 1906).

Joseph Bancroft Reade was born on 5th April 1801, at Leeds, Yorkshire. He was the eldest son of Thomas Shaw Bancroft Reade, a deeply religious man and the author of a series of pamphlets on Christian Experience and like topics, all issued as "by a layman"; his mother, Sarah Paley, was a member of the same family as Dr. William Paley, celebrated author of $A$ View of the Evidences of Christianity. With such a family background, it was almost inevitable that Joseph should go into the church; and so, indeed, he did. After an education successively at Leeds Grammar School and at Trinity and Caius Colleges, Cambridge, he gained his BA degree and became curate at Kegworth, Leicestershire, in 1825. He celebrated this appointment by marrying Charlotte Dorothy Farish whom he had met at Cambridge; they were to have three children, a son who dicd when only a year old, an elder daughter who died at 14 and a younger daughter who died unmarried at the age of 23 . The Reades remained at
Kegworth for four years, during which time Joseph took priests' orders in 1826 and gained his MA degree in 1828. In 1829 he moved closer to home, when appointed curate and afternoon lecturer at the parish church of Halifax, Yorkshire; but three years later he moved south, becoming incumbent of the parish of Harrow-on-the-Weald, near London.

From 1834 until 1839, however, Reade held no cure and seems to have lived in Peckham, London. It was during this time that his scientific work began. His father had somewhat unexpectedly presented him with a microscope when he was only 15 , and it was through this instrument that many of his original observations were made. His earliest scientific paper was $O n$ the existence of structure in the ashes of plants and their analogy to the osseous systems of animals (1837a). In this he demonstrated that: "by the agency of heat the surrounding siliceous matter may be liquefied, and the carbon and gaseous products of the wood dispelled, while the essential characters of the fibrous and cellular structure are undisturbed. The unconsumed portions, which alone constitute the true vegetable framework, are thus, as it were, mounted in the fluid silica". This led him to predict that the same structures would be found in the ashes of coal; and so it proved. This work was followed up in a second paper, in which he noted that: "the true framework and basis of vegetable structure in the plants of coal, is not only entirely independent of carbon, but it has also resisted the bituminous decomposition, which has converted all the carbonaceous materials into a highly inflammable substance" (1837b).

Though some of Reade's interpretations are confused, this work nonetheless made him a pioneer in the field of coal petrology and led on to the studies of microfossils discussed below. He was also to contribute to botany through his demonstration that spiral vessels in plant roots were not peculiar to monocotyledonous plants, as hitherto supposed, but also present in dicotyledons ( $1838 \mathrm{~b})$. The traditional view was so strongly held, however, that he found only ocular demonstration would serve to convince botanists that it was incorrect! Perhaps on the strength of these studies, Reade was elected a Fellow of the Royal Society in 1838, and in 1839 he became one of the original members of the Microscopical Society, later serving as its President (1869-1870).

The importance of Reade's contributions to the discovery of the chemical techniques used in photography has been a matter for prolonged argument. It seems that, in experiments conducted in March 1839 , Reade used an infusion of nut-galls on paper treated with silver nitrate in an attempt to increase its light sensitivity; sodium hyposulphite was used for fixing the photographic image. The result was eminently satisfactory. Reade described his experiments to 


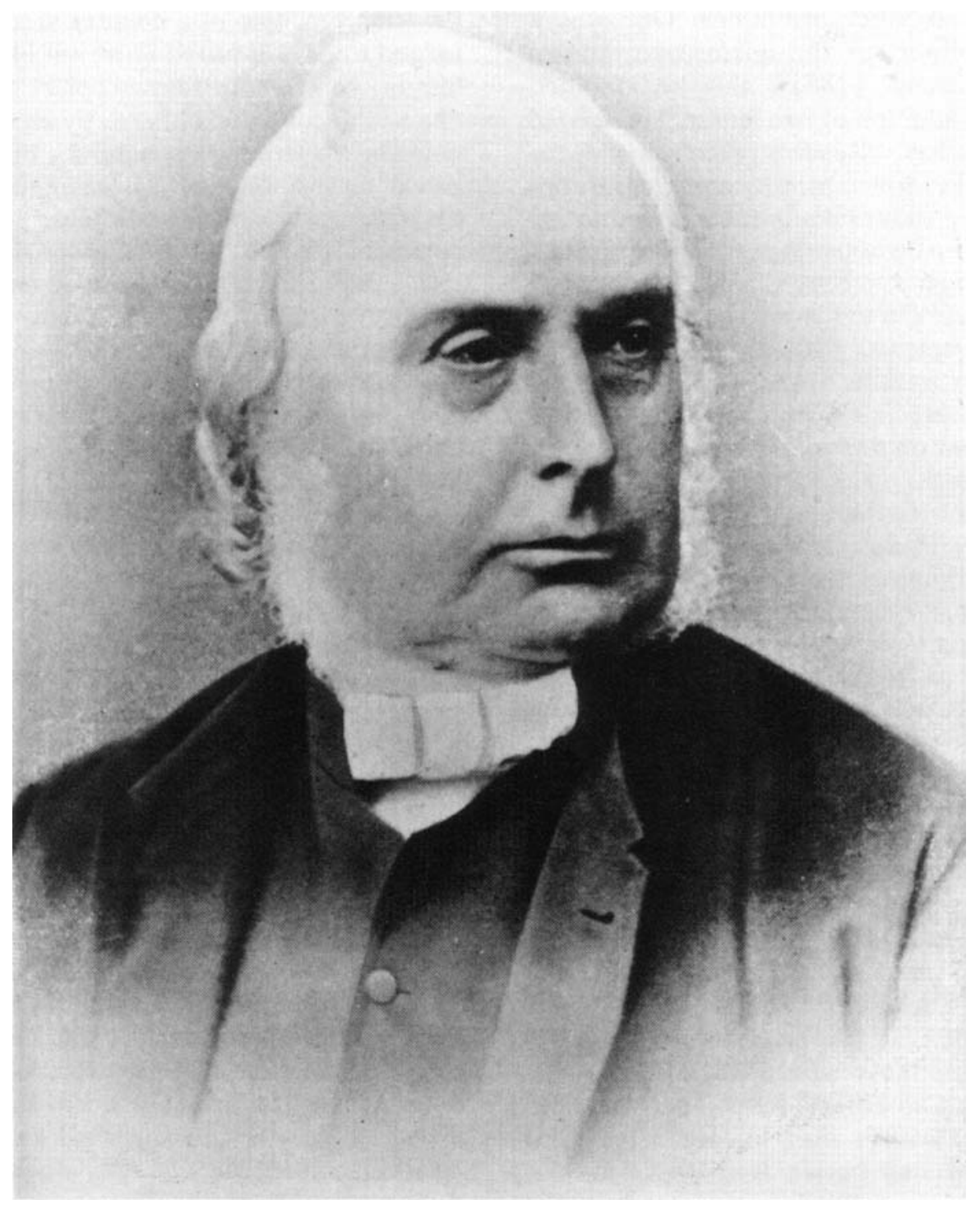

Fig. 1. Joseph Bancroft Reade, F.R.S. (1801-1870).

Andrew Ross, a London optician and instrument maker, who may in turn have mentioned the conversation to William Henry Fox Talbot (1800-1877). The process was also described in public lectures by Edward William Brayley (1802-1870), a chemist and populariser of science, during April and May 1839; though no account was published; Talbot may have learned of it through these lectures. Just over a year later, Talbot patented his calotype, or talbotype, technique which, with its use of gallic acid as developer of the latent image, was to be the basis for the modern photographic process. Did Talbot discover the process independently, or did he borrow and exploit Reade's discovery? The question was raised in a court case challenging Talbot's patent right in 1854 but was not resolved; it remains a source of controversy to this day (see Wood, $1971 \mathrm{a}, \mathrm{b}$,
1972).

Reade made several other contributions to photography. He discovered a method of separating heat-rays from those of light by the use of a hemispherical lens. In consequence, he succeeded in taking the first photomicrographs with the solar microscopes, exhibiting some of his "solar mezzotints" at the Royal Institution in London and elsewhere. He presented a paper on photographs of the moon and the sun at the meeting of the British Association for the Advancement of Science in 1854; and his photographs of the moon won honourable mention at the Paris exhibition of 1856. A paper on the use of gutta-percha as a substitute for glass was published in the Journal of the Photographic Society.

Reade's name was familiar to the microscopists of 
his time through two other inventions. One was a hemispherical condenser for the microscope, known as "Reade's kettledrum" (1861); this he modified subsequently by the addition of two lenses. The second was an equilateral prism, "Reade's prism", for microscopical illumination ( $1869 \mathrm{a}, \mathrm{b}$ ), which proved of considerable value in the study of diatoms and other microorganisms. He had also demonstrated the value of black ground illumination in microscopy (1839a) and lectured to the Royal Society, "On the construction and use of single achromatic eyepieces" (1840).

His scientific investigations were indeed diverse. He observed that ammonia was a product of respiration and presented a paper on Animal Ammonia, its formation, evolution and office to the British Association in 1858. He contributed further to biology through his observations on the cilia and ciliary currents of oysters (1845) and the morphology of diatoms (1869a), and to chemistry through his observations on two new salts of gold (1847) and on a method of forming ammonioiodides of metals (1857). He wrote on Roman coinmoulds for the Numismatic Chronicle (1839b) and was a member of the Royal Meteorological Society and of the Royal Astronomical Society. Rather improbably, this latter involvement advanced his career in the church, for in 1839 he was presented by that Society to the benefice of Stone, Buckinghamshire. He was to remain rector of Stone for twenty years, during which time he constructed an observatory at Stone Vicarage (described in the Monthly Notes of the Royal Astronomical Society for 1853-4).

From 1859 to 1863 , Reade was rector at nearby Ellesborough, Buckinghamshire; from 1863 at Bishopsbourne, near Canterbury, Kent. There he died of cancer, combined with a liver infection, on 12 th December 1870 and was buried four days later in Bishopsbourne churchyard. His interest in astronomy continued to the end of his life, for his observations on two meteors seen near Bishopsbourne on 16th October 1869 were published posthumously in 1871 .

In all, twenty-five scientific papers stand to Reade's credit in the Royal Society's list; but what was he like as a person?

An obituary notice in the Kent Herald (quoted by A.L. Reade, 1906, p. 99) gives a picture of him: "He lived so quietly and unobtrusively that many might have been constantly near him without knowing how great a man he was. One of his numerous friends happening one day to be visiting his former parish of Ellesborough and lighting on one who, from his age, appeared to be the 'oldest inhabitant', received for answer to his affectionate observations about the late Rector, 'Ah! sir, he was a homely man.' Such a reply showed the real greatness of the man who, although versed in the deepest mysteries of science, could adapt himself to the capacities and requirements of the simple people of a country village." Reade seems indeed to have inspired universal liking. The notice of him in the Monthly Microscopical Journal stated that "he will be long remembered by all who knew him, not only for his striking appearance, but for his kind and genial disposition, and his readiness to impart from the rich stores of his knowledge any information he possessed." The British Journal of Photography recalled that his "venerable appearance and gentle manner were extremely prepossessing. In the great world of science he has left not a single enemy", whilst the Popular Science Review commented: "He was a dear old man, and there must have been few who knew him that did not love him.",

\section{READE'S WORK ON THE "XANTHIDIA"}

Reade's work on the ashes of plants, and his recognition of a siliceous component in plant tissues, had been presented to the British Association in September 1837. It had attracted the attention of Gideon Mantell, who was greatly interested in the nature of fossils and the processes of fossilization; and soon the two were in correspondence. Mantell referred extensively to Reade's work in the eighth of a series of public lectures presented at Brighton, Sussex. Notes taken from these lectures were brought together by G.F. Richardson, the Curator of the Mantellian Museum in Brighton; and when these were published in two volumes early in 1838 under the title The Wonders of Geology, one of Reade's letters was included in the appendices. This has hitherto escaped notice among historians of micropalaeontology, yet it is of considerable interest, for it includes the earliest depiction of a fossil dinoflagellate cyst to be published in Britain - or, indeed, anywhere outside Germany and France. In the letter, Reade commented that: "My original inquiry having thus conducted me to the conclusion, that siliceous organization is not destructible by the agency of heat, I thought it not unreasonable to infer that a careful and more extended microscopic examination into the condition of silica, might lead to the discovery of elementary organic forms, even in the primitive strata themselves ... Moreover, there appeared to be a strong suspicion in some minds, that every successive surface of our globe had been characterized by its own minute living forms; and that you, yourself, had more than once contended for the existence of life during the granitic period" (Reade, 1838a, p. 685). Reade was here referring to Mantell's belief that life had existed during the period we would now call the Precambrian, whose rocks consisted of granites and of sediments metamorphosed into slates and schists. Mantell recognized that the remains of organisms would largely have been destroyed by the metamorphic process; but he was hopeful that "siliceous skeletons of animalcules" might have survived (1838, p. 659). In a direct sense, 
Mantell was unduly optimistic; but, in an indirect sense, his hope was to be fulfilled more than a century later, with the discovery of preserved microfossils in the Precambrian Gunflint cherts of Canada and similar rocks of Africa and Australia. Reade continued: "To give a reality, however, to a first condition, thus pronounced to be probable, we must discover the skeletons of animalcules even in granite itself. But here arises a difficulty which will baffle our utmost ingenuity to remove; for, though, on the one hand, $\|$ meet with siliceous corpuscles in the primitive rocks, and find, on the other hand, that the indestructible organic skeletons of recent infusoria exhibit, even under a power of 900 linear, a striking similarity of form, yet the entire absence of external structure precludes me from assigning a common animal origin to the ancient and recent organisms. Still, the enquiry, even in its present state, is far from being fruitless: for it cannot but be a matter of surprise, that immense mountain masses should have been found to consist of an aggregation of symmetrical bodies, between $1 / 5,000$ and $1 / 10,000$ of an inch in diameter, articulated together in the form of rings, as in chalk, or of slender threads, as in limestone, and the quartz of granite, and that an exact counterpart of this curious structure in the mineral kingdom should be exhibited in the vegetable, by the mouldiness of paste, and in the animal by the Gaillonella ferruginea" (idem). The "symmetrical bodies" in chalk to which Reade referred were coccoliths. The nature of his "slender threads" is less clear; those in limestone might well have been microfossils, but those in quartz surely were not.

By this time Reade was certainly familiar with Ehrenberg's results, for he noted that he had read, in the Philosophical Magazine for April 1837, "a short note by Professor Ehrenberg" and also "the valuable papers of the same author, published originally in 'Poggendorf's Annalen' [Ehrenberg, $1836 \mathrm{a}, \mathrm{b}$ ] and lately given to the English reader in 'Scientific Memoirs', vol. I pt. iii" (ibid., p. 686). [This last reference is to Taylor's Scientific Memoirs (Ehrenberg, 1837 a, b), which Mantell proceeded to abstract in two paragraphs following Reade's letter.] The degree to which Reade's studies had anticipated, or had run parallel to, those of Ehrenberg is left unclear; in particular, we have no information concerning the nature of the "more than thirty microscopical illustrations" that had accompanied Reade's presentation to the British Association in Liverpool. However, in regard to the matter of Ehrenberg's priority as discoverer of fossil dinoflagellate cysts, there can be no doubt; for Reade's single illustration of one found "in the flint of Sydenham" shows his familiarity not only with the German microscopist's work but with that of Turpin also (see caption, Reade, 1838a,tab. 80; and herein, Fig. 2). Furthermore, it seems that Reade made his identification by means of comparison with a French specimen "then but just imported at an expense exceeding 20 francs" (1839, p. 193). Was it that Ehrenberg's work was already being followed up by commercial microscopists in France,
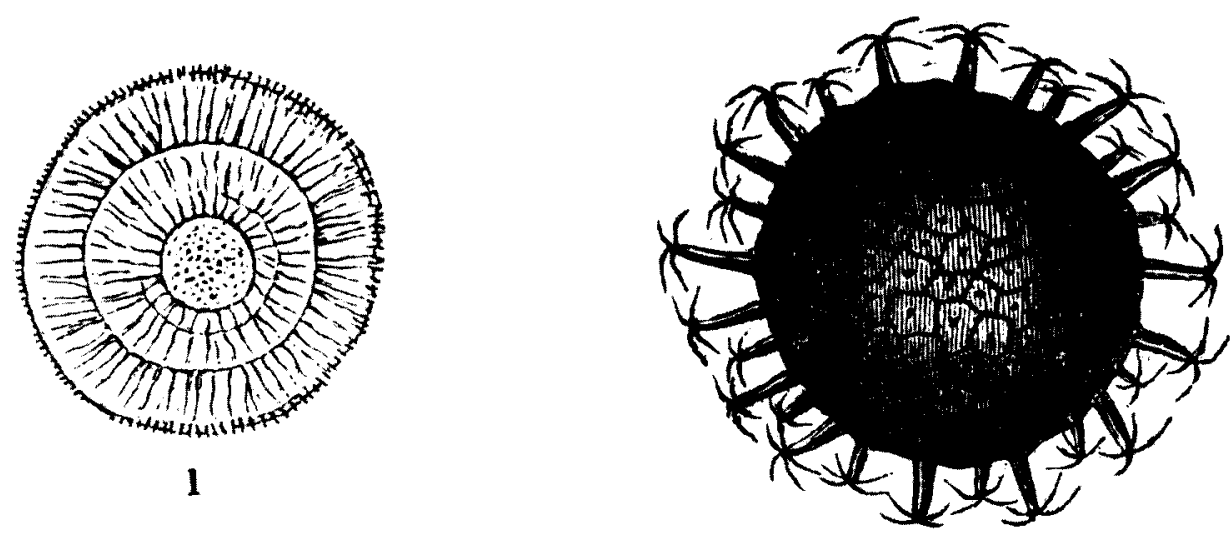

2

Fig. 2. "Infusoria in Flint (highly magnified): 1. Body unknown - formed of three distinct circles: the intervening spaces are filled with numerous delicate rays, and the exterior circle is sinuous and fringed. From the flint of Sydenham in Kent. 2. Supposed by M. Turpin to be the egg of a Polype (Christatelle vagabonde), but is the Xanthidium furcatum of Ehrenberg. This fossil animalcule occurs with the former in the flint of Sydenham." (Reproduced from Reade, 1838a, Tab. 80). 


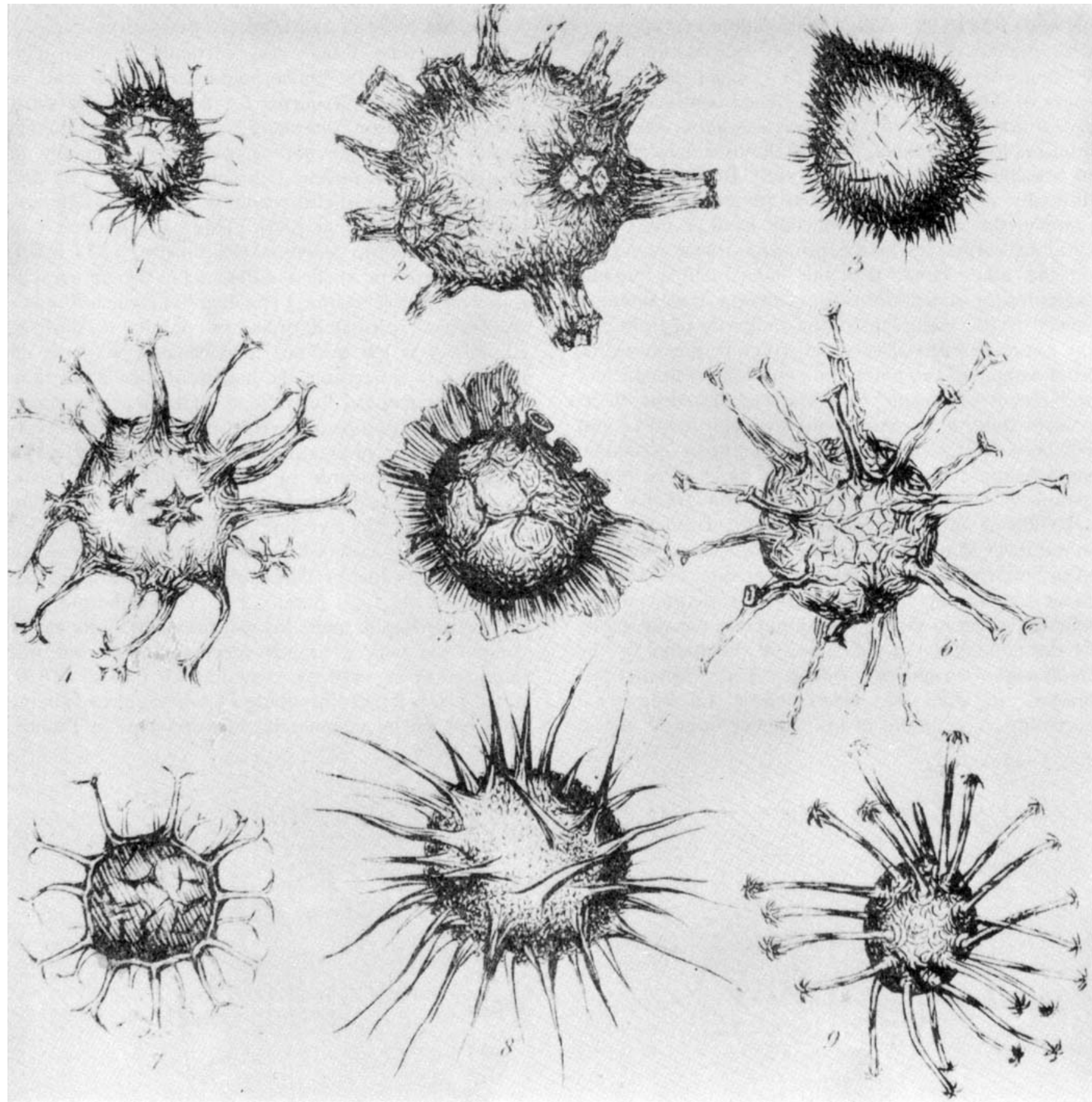

Fig. 3. "Infusoria in flint: 1. Xanthidium furcatum. 2. X.crassipes -5 Do var. 3. X.hirsutum - 8 D-.4. X.ramosum7 D.. 6. X.tubiferum-9 Do." (Reproduced from Reade 1838c, pl. 9; for modern names of these cysts, see text).

or was this bought from Turpin?

Reade's letter is dated Peckham, December 1837. During the following year, he was to have the pleasure of meeting Ehrenberg when the German naturalist visited England in the summer of 1838. Later, Reade noted $(1839$, p. 140$)$ that he had shown Ehrenberg some specimens of fish scales from flint flakes, and that such fossils had been previously unknown to Ehrenberg. One must presume it was during this visit that Ehrenberg named for Reade the species of Xanthidium he was soon to illustrate.

Reade's paper on the flint microfossils was submitted to press, again from Peckham, on 5th October 1838 and published a month later (not in 1839, the date 
usually cited). Much of it was concerned with his discovery of the fish scales: fossil scales are illustrated in his first plate (pl. VIII) and comparable modern scales are illustrated in the upper third of his second plate (pl. IX). Figures of "infusoria" make up the remainder of that plate (Fig. 3). They are allocated to five species: Xanthidium furcatum Ehrenberg, $X$.hirsutum Ehrenberg, X.ramosum Ehrenberg, $X$.tubiferum Ehrenberg, and a new species, $X$.crassipes. Reade commented: "It is now well known that flint of every kind is rich in organic remains, and few persons who use the microscope at all, have neglected the examination of these minute forms which had their little moment of life and enjoyment in ages of the -most remote antiquity" (1838c, p. 193). Ehrenberg's discoveries had indeed, it seems, been swiftly followed up by microscopists at large! Reade's next observation is particularly intriguing: "Perhaps, however, it is not so generally understood that, in the hands of a skillful geologist, a promiscuous series of flint pebbles would be assigned, with the utmost precision, and by means of their fossil contents alone, to their proper periods and strata. Yet such is the fact, and I have had the pleasure of seeing it verified by my friend Mr. Bowerbank, who lately took advantage of a geological tour to establish this curious result. I had, indeed, myself suspected that the flint of different strata had not a common origin, in consequence of the absence of Xanthidium from many of the pebbles of the Brighton beach" (idem). Thus did Reade recognize the potential biostratigraphical importance of dinoflagellate cysts, some 120 years before it came to be realized by geologists at large!

Reade's friend James Scott Bowerbank (1797-1877) owned a distilling business that provided ample funds and leisure for his interests in geological and microscopical research. His observations on the "xanthidia" were included in a paper read to the Geological Society of London on 11th March 1840 and published thrice, though always without illustration of the "xanthidia" (1841 a, b, c). Mantell and Reade were certainly, Bowerbank probably, members of the Clapham Microscopical Society, apparently a section (formally or informally organized) within the Clapham Athenaeum; other members concerned with "xanthidia" included Henry Deane (1807-1874), Henry Hopley White and perhaps Samuel J. Wilkinson. The work of this group of British microscopists is summarized in an earlier paper (Sarjeant, 1967) in which the particular importance of Mantell's contributions to the study of fossil dinoflagellate cysts, in particular his recognition that they were organic, not siliceous, in chemical constitution is stressed. It was, indeed, probably by interesting Mantell in the "xanthidia" that Reade made his most lasting contribution to our knowledge of these microfossils.

\section{THE PRESENT ATTRIBUTION OF READE'S "XANTHIDIA"}

Of the specimens of "xanthidia" illustrated (only in a few instances were they described) by English microscopists of the mid-19th century, only one, the holotype of Spiniferites reginaldi Mantell, now lodged in the British Museum (Natural History), is known still to survive (Sarjeant, 1967). Those of Reade are long lost, so that any conclusions on their nature and affinity must be based exclusively on his figures.

All are nowadays recognized as proximochorate or chorate dinoflagellate cysts. The species furcatum and ramosum are now considered as elements within a single morphological plexus, to which the name Spiniferites ramosus (Ehrenberg) Mantell is applied (see Sarjeant, 1970). They are closely comparable with the encysted stage in the life cycle of the modern dinoflagellate species Gonyaulax spinifera (see Wall \& Dale, 1970).

Neither of the two forms figured by Reade as "Xanthidium hirsutum" would nowadays be placed into that species. The second was later figured anew by H.H. White (1842) and, on the basis of his illustration rather than Reade's, has subsequently been distinguished as a separate species, Cometodinium? whitei (Deflandre \& Courteville) Stover \& Evitt. The species tubiferum Ehrenberg is now the type of the genus Hystrichosphaeridium; but Reade's specimen is attributable to a different species of that genus erected by White himself, Hystrichosphaeridium? palmatum (White ex Bronn) Sarjeant. [For discussions of the nomenclatural problems presented by this species see Sarjeant, 1964, p. 173-174, and Stover \& Evitt, 1978, p. 57].

In the lack of Reade's holotype, a modern analysis of his species crassipes presents particular difficulties. To resolve them, it has been proposed recently that a Belgian specimen assigned to that species by LejeuneCarpentier (1941) be selected as neotype and an emended diagnosis, based on that neotype, has been proposed. Its present generic assignment is tentative, as Hystrichokolpoma? crassipes (see Lejeune-Carpentier \& Sarjeant, 1981).

\section{ACKNOWLEDGEMENTS}

I am indebted to Mr. R. Derek Wood (Institute of Opthalmology, London) for drawing my attention to the publication of Reade's letter in the first edition of The Wonders of Geology and for critically reading, more than a decade ago, the earliest draft of this paper. My work was completed at the University of Saskatchewan, supported by National Research Council of Canada operating grant A 8393 . 


\section{REFERENCES}

Anon. 1871. Obituary: Joseph Bancroft Reade. Trans. R.microsc.Soc., 92-96.

Anon. 1871. Obituary: Joseph Bancroft Reade. Mon. microsc. J., 5, 92.

B-, G.S., 1917. Reade, Joseph Bancroft (18011870). In Stephen, Sir L., \& Lee, S. (Eds.) Dictionary of Scientific Biography, London, 16, 803-804.

Bowerbank, J.S. $1841 \mathrm{a}$. On the siliceous bodies of the Chalk, Greensands and Oolite. Proc.geol.Soc. London, 3, 278-281.

Bowerbank, J.S. $1841 \mathrm{~b}$. On the siliceous bodies of the Chalk, Greensands and Oolite. Micr.J.struct.Rec., London, 2, 99-103, 113-115, 131-135, 4 text-figs.

Bowerbank, J.S. $1841 \mathrm{c}$. On the siliceous bodies of the Chalk, Greensands and Oolite. Trans.geol.Soc., London, 2, 181-194, pls. 18-19.

Curwen, E.C. 1940. The journal of Gideon Mantell, surgeon and geologist. 315 pp., frontis. +4 pls. Oxford.

Ehrenberg, C.G. 1836a. Vorlaufige Mitteilungen über das wirkliche Vorkommen fossiler Infusorien und ihre grosse Verbreitung. Annln Phys.Chem., Leipzig, 38, 213-227.

Ehrenberg, C.G. 1836 b. Weitere vorlaufige Nachrichten über fossile Infusorien. Annln Phys.Chem., Leipzig, 38, 455-464.

Ehrenberg, C.G. 1837a. Remarks on the real Occurrence of Fossil Infusoria, and their extensive Diffusion. Scient.Mem., London, 1, 400-407.

Ehrenberg, C.G. 1837b. Further Notices of Fossil Infusoria. Scient.Mem., London, 1, 407-413.

Ehrenberg, C.G. 1837c. Uber die fossilen InfusorienGattungen Xanthidium und Peridinium. Arch. Naturgesch., Berlin, 3, 227-238. (Republ. in Froriep's Notizen, 1838, 5, cols. 57-58).

Ehrenberg, C.G. 1838. Uber das Massenverhaltnis der jetzt labenden Kiesel-Infusorien und über ein neues Infusorien-Conglomerat als Polierschiefer von Jastraba in Ungarn. Abh.Akad.Wiss., Berlin, 1, $109-135$.

Lejeune-Carpentier, M. \& Sarjeant, W.A.S. 1981. Restudy of some larger dinoflagellate cysts and an acritarch from the Upper Cretaceous of Belgium and Germany. Ann.Soc.géol.Belg., Liège, 104, 1-39, pls. 1-5, text-figs. 1-2.

Mantell, G.A. 1838. The wonders of geology; or, a familiar exposition of geological phenomena; being the substance of a course of lectures delivered at Brighton. From the notes taken by G.F. Richardson. 2 vols., $\mathrm{xvi}+376+[20]$ pp., ix $+377-689+[23]$ pp., 6 pls., 80 "tabs." [text-figs.] London.

Morris, A.D. 1972. Gideon Algernon Mantell LL.D., F.R.C.S., F.R.S. (1790-1852), Surgeon and Geologist: "Wizard of the Weald". Proc.R.Soc.Med., London, 65, 215-222, 4 text-figs.
Reade, A.L. 1906. The Reades of Blackwell Hill in the parish of Horton, Staffordshire: a record of their descendants; with a full account of Dr. Johnson's ancestry, his kinsfolk and family connexions. $\mathrm{xx}+$ $283+$ xii pp., frontis, 17 pls., 29 tabs. London (pp. 90-99, pl. 16 relevant).

Reade, J.B. 1837a. On the existence of structure in the ashes of plants and their analogy to the osseous systems of animals. Phil.Mag., London, 11, 13-17.

Reade, J.B. $1837 \mathrm{~b}$. Observations on the structure of the solid materials found in the ashes of recent and fossil plants. Phil.Mag., London, 11, 413-417.

Reade, J.B. 1838a. On Fossil Infusoria: in a Letter to Gideon A. Mantell, Esq. LL.D. \&c. In Mantell, G.A., The wonders of geology, q.v. (pp. 684-688, "tabs." 78-80).

Reade, J.B. $1838 \mathrm{~b}$. On the existence of spiral vessels in the roots of dicotyledonous plants. Ann.nat.Hist., London, 1, 111-113.

Reade, J.B. 1838c. On some new Organic Remains in the Flint of Chalk. Ann.nat.Hist., London, 1, 191-198, pls. 8-9.

Reade, J.B. 1839a. A new method of illuminating microscopic objects. Sturgeon, Ann.electr., London, 4, (1839-40), 407-409.

Reade, J.B. 1839b. On the Roman Coin Moulds discovered in France and England. Numismatic Chronicle, London, 1, 147-165.

Reade, J.B. 1840. On the construction and use of single acromatic eye-pieces, and their superiority to the double eye-piece of Huyghens. Proc.R.Soc., London, 4, 195.

Reade, J.B. 1845. On the cilia and ciliary currents of the Oyster. Rep.Br.Ass.Advmt.Sci., London, 66-67.

Reade, J.B. 1847. On two new salts of Gold. Rep.Br. Ass.Advmt.Sci., London, 57.

Reade, J.B. 1854a. On the Observatory at Stone Vicarage, near Aylesbury. Mon.Notes astron.Soc., 14, (1853-54), 196-198.

Reade, J.B. $1854 \mathrm{~b}$. On photographs of the Moon and of the Sun. Rep.Br.Ass.Advmt.Sci., London, 10-12.

Reade, J.B. 1857. On a new method of forming ammonioiodides of metals. Rep.Br.Ass.Advmt Sci., London, 55-57.

Reade, J.B. 1858. On Animal Ammonia, its formation, evolution and office. Rep.Br.Ass.Advmt Sci., London, 65-66.

Reade, J.B. 1861. New hemispherical condenser for the microscope. [Presented to the Royal Microscopical Society; paper not traced.]

Reade, J.B. $1869 \mathrm{a}$. On the diatom prism, and the true form of diatom markings. Mon.microsc.J., London, 2, 5-11.

Reade, J.B. $1869 \mathrm{~b}$. On the microscope prism and the structure of the Podura scale. Mon.microsc.J., London, 2, 7. 
Reade, J.B. 1870. President's Address to the Royal Microscopical Society, March 1st 1870. Mon. microsc.J., London, 3, 113-133.

Reade, J.B. 1871. Account of two meteors seen at Bishopsbourne 16.Oct.1869. Proc.Br.meteorol.Soc., London, 5, 21-22.

Sarjeant, W.A.S. 1964. Taxonomic notes on hystrichospheres and acritarchs. J. Paleont., Chicago, 38, 173-177.

Sarjeant, W.A.S. 1967. The Rediscovery of a Lost Species of Dinoflagellate Cyst: Hystrichosphaera (ex: Spiniferites) reginaldi (Mantell, 1844) comb. nov. Microscopy, London, 30, 241-250, 1 pl.

Sarjeant, W.A.S. 1970a. Xanthidia, Palinospheres and 'Hystrix'. A review of the study of fossil unicellular microplankton with organic cell walls. Microscopy, London, 31, 221-253, figs. 1-12.

Sarjeant, W.A.S. 1970b. The genus Spiniferites Mantell, 1850 (Dinophyceae). Grana, Stockholm, 10, 74-78.

Spalding, D.A.E. 1966. Biographical notes of authors on Derbyshire: Gideon Algernon Mantell (17901852). Bull.Peak Distr.Mines his.Soc., Sheffield, 3, $85-92$.

Spokes, S. 1927. Gideon Algernon Mantell: surgeon and geologist. $\mathrm{xv}+263$ p., 5 pls. London.
Stover, L.E. \& Evitt, W.R. 1978. Analyses of PrePleistocene Organic-Walled Dinoflagellates. Stanf. Univ.Publ.Geol.Sci., Stanford, USA 15, 300 pp.

Swinton, W.E. 1975. Gideon Algernon Mantell. Br.med.J., 505-507.

Turpin, C.R. 1837. Analyse ou étude microscopique des différents corps organisés et autres corps de natur diverse que peuve, accidentellement, se trouver envellopper dans le pâte translucide des silex. C.R.Acad.Sci., Paris, 4, 304-314, 351-362.

Wall, D. \& Dale, B. 1970. Living hystrichosphaerid dinoflagellate spores from Bermuda and Puerto Rico. Micropaleontology, London, 16, 47-58, pl. 1, textfigs. 1-22.

Wood, R.D. 1971 a. J.B. Reade, F.R.S., and the early history of photography. 1. A re-assessment on the discovery of contemporary evidence. Ann.Sci., 27, 13-45, pl. 12.

Wood, R.D. 1971b. J.B. Reade, F.R.S., and the early history of photography. II. Gallic acid and Talbot's Calotype Patent. Ann.Sci., 27, 47-83.

Wood, R.D. 1972. J.B. Reade's Early Photographic Experiments. Br.J.Phot., 119, 643-647, 1 fig. 